\title{
An Adult Cervical Intramedullary Arachnoid Cyst: Case Report and Review
} Lino Fonseca* and Bernardo Ratilal

Department of Neurosurgery, Centro Hospitalar Lisboa Central-Hospital São José, Rua José António Serrano, Portugal

*Corresponding author: Lino Fonseca, Department of Neurosurgery, Centro Hospitalar Lisboa Central-Hospital São José, Rua José António Serrano, Portugal, Tel: 00351918105799; E-mail: dafonsecalino@gmail.com

Rec Date: July 17, 2017; Acc Date: August 09, 2017; Pub Date: August 14, 2017

Copyright: $\odot 2017$ Fonseca L, et al. This is an open-access article distributed under the terms of the Creative Commons Attribution License, which permits unrestricted use, distribution, and reproduction in any medium, provided the original author and source are credited.

\section{Abstract}

Spinal arachnoid cysts are uncommon benign lesions that occur in the spinal axis, and can cause spinal cord or nerve roots compression and may become clinically relevant.

The authors report a 49-year-old woman who presented progressive onset of cervical pain with distal paraesthesia of the upper limbs associated to an intramedullary arachnoid cyst in the mid-cervical spine diagnosed by MRI.

From the literature review, only six cases in patients over 18-year-old were found, all with thoracic location and one with cervical extension, and all were submitted to decompressive surgery.

The authors described the first intramedullary arachnoid cyst with a wait and scan approach.

Keywords: Intramedullary; Arachnoid cyst; Cervical; Adult

\section{Introduction}

Spinal arachnoid cysts, also called arachnoid diverticula, are uncommon benign lesions that occur in the spinal axis [1]. They are often diagnosed incidentally. Nonetheless, they are known to cause spinal cord or nerve roots compression and become clinically relevant in rare cases [2-4]. The pathogenesis of these lesions remains unclear, and various causes, including congenital, traumatic or inflammatory, are proposed [5]. Nabors et al. classified them, according to their location, as: Type I-extradural without spinal nerve root fibers; Type II-extradural with spinal nerve root fibers; Type III-intradural [6]. Extradural cysts arise from arachnoid herniation through small flaws of the dura mater, while the intradural develop mainly from changes of the arachnoid trabeculae.

Intramedullary arachnoid cysts are extremely rare, especially in adult population. There are only six cases reported in the literature, in patients over 18-year-old, all with thoracic location [6-11].

Here in, we report the case of a 49-year-old woman who presented with progressive onset of cervical pain associated with distal paraesthesia of the upper limbs secondary to an intramedullary arachnoid cyst in the mid-cervical spine.

\section{Case Report}

A 49-year-old female presented with a 5-year history of progressive cervical pain with episodic worsening and posteriorly aggravated with bilateral distal paraesthesia of the upper limbs. The cervical CT scan revealed minor degenerative spondylosis. The patient was referred to our Neurosurgery Department, at Centro Hospitalar Lisboa Central in Lisbon. At the time of admission, the patient had only a minor nonconsistent distal hypoesthesia of both upper limbs. The remainder physical examination was unremarkable. Medical or family history was irrelevant.

The patient underwent spinal MRI, which showed a cystic intramedullary lesion at the C6-C7 level, hipointense on T1-weighted images and hyperintensity on T2-weighted images with no peri lesion edema and no contrast enhancement (Figure 1).

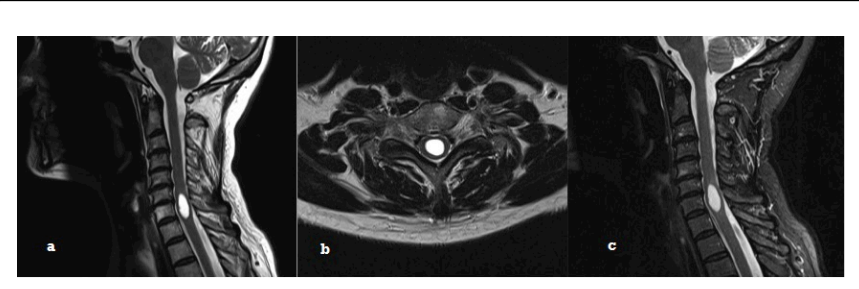

Figure 1: a) T2-weighted MRI, sagittal view, showing intramedullary arachnoid cyst in C6-C7 b) T2-weighted MRI, axial view, showing round intramedullary arachnoid cyst in the centre of the cord c) T2-weight with contrast MRI, sagittal view, showing intramedullary cyst lesion without enhancement.

It was decided for a conservative approach ("wait and scan") with periodic MRI imaging control and regular neurological revaluation. It was confirmed the stability of the cystic lesion over time, with no signs suggestive of medullary suffering. Seriated neurological revaluation was uneventful during the five years follow-up.

\section{Discussion}

Spinal arachnoid cysts are a rare cause of spinal cord compression. Most cases are incidental findings detected on imaging evaluations for other reasons [6]. In a series of 99 children, held by Campagna et al. between 1 years and 6 years of age that underwent decompressive surgery for spinal cord compression, only 1 case it was an arachnoid 
cyst [12]. Intramedullary arachnoid cysts are even rarer, and since its first description by Aithala et al. in 1999 [13], only 15 cases have been reported in the literature, mostly on paediatric population [3,4,6-11,13-18] (Table 1).

\begin{tabular}{|c|c|c|c|c|}
\hline Authors & Sex/Age & Clinical findings & Level & Outcome/follow-up \\
\hline \multirow[t]{4}{*}{ Goyal et al. [7] } & \multirow[t]{4}{*}{$\mathrm{F} / 63$} & Spastic paraparesis $(1 / 5)$ & \multirow[t]{4}{*}{ T9-L2 } & \multirow[t]{3}{*}{ Good recovery (powerlimbs grade $4 / 5$; remains catheterized) } \\
\hline & & Sensory loss below L1 & & \\
\hline & & Urine retention & & \\
\hline & & & & 3 months \\
\hline \multirow[t]{2}{*}{ Gezici et al. [6] } & \multirow[t]{2}{*}{$\mathrm{F} / 35$} & \multirow[t]{2}{*}{ Spastic paraparesis $(1 / 5)$} & \multirow[t]{2}{*}{ T5-T6 } & Good recovery) able to walk with little difficulty) \\
\hline & & & & 3 years \\
\hline \multirow[t]{3}{*}{ Diyora B et al. [8] } & \multirow[t]{3}{*}{$\mathrm{F} / 45$} & Flaccid paraplegia & \multirow[t]{3}{*}{ T4-T5 } & Complete recovery (relief of pain and motor power \\
\hline & & Back pain & & \\
\hline & & & & 1.5 months \\
\hline \multirow[t]{2}{*}{ Kataria R et al. [9] } & \multirow[t]{2}{*}{$\mathrm{F} / 40$} & paraparesis & \multirow[t]{2}{*}{ L1 } & Complete recovery \\
\hline & & Urinary symptoms & & 1 month \\
\hline \multirow[t]{2}{*}{ Rahimizadeh A et al. [10] } & \multirow[t]{2}{*}{$\mathrm{F} / 58$} & Progressive quadriparesis & \multirow[t]{2}{*}{ C6-T2 } & Complete recovery \\
\hline & & Difficulty in walking & & 3 years \\
\hline \multirow[t]{2}{*}{ Novegno F et al. [11] } & \multirow[t]{2}{*}{$F / 31$} & $\begin{array}{l}\text { Spastic paraparesis (inability } \\
\text { walk/stand) }\end{array}$ & \multirow[t]{2}{*}{ T11-T12 } & Complete recovery \\
\hline & & Bowel dysfunction & & 2 years \\
\hline
\end{tabular}

Table 1: Literature review of patients with spinal intramedullary arachnoid cysts.

Usually arachnoid cysts accompany others defects of maturation of the neural tube. In 1937, Voss first described the association between congenital cysts and dysraphic anomalies [4]. Later, Rabb et al. reinforced this observation presenting a series of 11 patients between 19 months and 18 years of age who had spinal arachnoid cysts, with 6 of these presenting also a myelomeningocele [19].

Because of the rarity of this disease, many questions remain unanswered, particularly with regard to their etiopathogenic mechanisms, its natural history and its best therapeutic approach.

There are several theories about the development of intradural arachnoid cysts that are divided into five main categories: i) congenital; ii) arachnoid adhesions secondary to inflammatory processes; iii) arachnoiditis due to bleeding, contrast, anaesthetics, fibrin glue and bone powder; iv) traumatic; v) idiopathic [20].

Fortuna and Mercuri in 1983 supported the hypothesis proposed by Hyndman and Gerber previously, that describes the presence of congenital arachnoid granulations in abnormal locations, with prevalence at the thoracic level, leading to cystic development [21].

The behaviour of the arachnoid cysts remains undefined, since some remain quiescent over time, others become symptomatic, and reabsorption has been described rarely [7].
Agnoli et al. reported that after the formation of arachnoid cyst, the degeneration of the trabeculae arachnoid cells leads to an increase of the osmotic effect and the consequent cystic growth [22]. Catala and Poirier describe a mechanism based on a unidirectional valve associated with an increased secretion of the cyst wall cells to contribute to the enlargement of the cyst [23].

According to the various theories presented, we can define the intramedullary arachnoid cysts as a dynamic entity. Novegno et al. reported a case of an increasing spinal cystic lesion that supports this theory [11].

All cases of purely intramedullary arachnoid cysts reported in the literature showed a growth overtime accompanied by sudden neurological deterioration, requiring immediate surgical evacuation [3,4,6-11,13-18]. To date, there is no existing literature on a quiescent intramedullary arachnoid cyst detected incidentally in an asymptomatic subject [10]. The case reported in this article is the first to oppose the theory of dynamical presentation, in which there was no clinical or imaging progression and where a conservative approach was opted.

MRI is the gold standard diagnostic tool for all types of spinal arachnoid cysts, as it has the ability to provide information on the exact location, extent and cyst relation to the spinal cord [24]. They are typically hyperintense on T1-weighted images and hyperintense on T2- 
weighted images, with no contrast enhancement or perilesional edema thus excluding tumours, infectious diseases and idiopathic syringomyelia. The differential diagnosis must include primarily neuroepithelial, neuroenteric cysts and parasitic cyst, namely hydatid $[25,26]$.

The neuroenterics cysts originate from abnormal development of the remnants of the notochord (origin in the endoderm). These are often associated with severe neurovertebral developmental abnormalities, including diastematomyelia, which was not observed in the reported case. Neuroepithelial intradural cysts arise from the proliferation of ectopic ependymal cells, primarily in the anterior portion of the spinal cord, with a preferential distribution on the thoracolumbar region, in particular the cone-caudal segment; this aspect does not take place in this case, since the lesion are localized in the cervical segment, and does not include anterior intramedullary positioning [21]. Regarding hydatid cysts, we usually have a suspicion in endemic areas and concomitant liver lesions, which did not occur.

All cases reported in the literature so far showed a surgical treatment, with fenestration and partial removal of the cyst wall. None of these showed worsening of the preoperative neurological deficits. Instead all the patients presented a clear improvement during the first weeks following the procedure, which was independent from the duration or severity of symptoms [3,4,6-11,13-18]. The authors report the only published case of intramedullary adult arachnoid cyst with neurological stability during follow-up (five years), and managed with a wait and scan approach.

\section{Conclusion}

Despite the extreme rarity of intramedullary arachnoid cysts in the cervical segment, especially in the adult, they should be considered in the differential diagnosis of intramedullary cystic lesions. Although surgery is the preferred approach in this type of pathology, if the patient is asymptomatic a wait and scan approach may prove to be a good therapeutic choice.

\section{References}

1. Kazan S, Ozgur O, Mahmut A, Tuncer R (1999) Spinal intradural arachnoid cysts located anterior to the cervical spinal cord. J Neurosurg (2 Suppl) 91: 211-215.

2. Lee HJ, Cho DY (2001) Symptomatic spinal intradural arachnoid cysts in the pediatric age group: Description of three new cases and review of the literature. Pediatr Neurosurg 35: 181-187.

3. Lmejjati M, Aniba K, Haddi M, Hakkou M, Ghannane H, et al. (2008) Spinal intramedullary arachnoid cyst in children. Pediatr Neurosurg 3: 243-246.

4. Medved F, Seiz M, Baur MO, Neumaier-Probst E, Tuettenberg J (2009) Thoracic intramedullary arachonid cyst in an infant. J Neurosurg Pediatr 3: 132-136.

5. Nabors MW, Pait TG, Byrd EB, Karim NO, Davis DO, et al. (1988) Updated assessment and current classification of spinal meningeal cysts. J Neurosurg 68: 366-377.
6. Gezici AR, Ergun R (2008) Intramedullary arachnoid cyst: 3-year follow up after bilateral dorsal root entry zone myelotomy. Acta Neurochir (Wien) 150: 595-597.

7. Goyal A, Singh AK, Singh D, Gupta V, Tatke M, et al. (2002) Intramedullary arachnoid cyst. Case report. J Neurosurg (1 Suppl) 96: 104-116.

8. Diyora B, Kamble H, Nayak N, Dugad P, Sharma A (2010) Thoracic intramedullary arachonid cyst. Neurol India 58: 964-966.

9. Kataria R, Sinha VD, Chopra S (2012) Intramedullay arachnoid cyst: Report of two cases. Neurol India 60: 123-124.

10. Rahimizadeh A, Soufiani H (2013) Intramedullary arachnoid cyst in association with cervical spondylosis: Case report. Spine J 13: 21-25.

11. Novegno F, Umana G, Muro L, Fraioli B, Fraioli MF (2014) Spinal intramedullary arachnoid cyst: case report and literature review. Spine J 14: 9-15.

12. Campagna MJ, Dodge HW, Keith HM (1956) Intraspinal tumors in infants and children. J Int Coll Surg 26: 199-215.

13. Aithala GR, Sztriha L, Amirlak I, Devadas K, Ohlsson I (1999) Spinal arachnoid cyst with weakness in the limbs and abdominal pain. Pediatr Neurol 20: 155-156.

14. Sharma A, Sayal P, Badhe P (2004) Spinal intramedullary arachnoid cyst. Indian J Pediatr 71: 65-67.

15. Sharma A, Karande S, Sayal P, Ranadive N, Dwivedi N (2005) Spinal intramedullary arachnoid cyst in a 4-year-old girl: A rare cause of treatable acute quadriparesis: Case report. J Neurosurg (4 Suppl) 102: 403-406.

16. Ghannane H, Haddi M, Aniba K (2007) Symptomatic intramedullary arachnoid cyst. Report of two cases and literature review. Neurochirurgie 53: 54-57.

17. Guzel A, Tatli M, Yilmaz F, Bavbek M (2007) Unusual presentation of cervical spinal intramedullary arachnoid cyst in childhood: Case report and review of the literature. Pediatr Neurosurg 43: 50-53.

18. Bond AE, Zada G, Bowen I, McComb JG, Krieger MD (2012) Spinal arachnoid cysts in the pediatric population: Report of 31 cases and a review of the literature. J Neurosurg Pediatr 9: 432-441.

19. Rabb CH, McComb JG, Raffael C, Kennedy JG (1992) Spinal arachnoid cysts in pediatric age group: An association with neural tube defects. J Neurosurg 77: 369-372.

20. Kumar K, Malik S, Schulte P (2003) Symptomatic spinal arachnoid cysts: Report of two cases with review of the literature. Spine 28: 25-29.

21. Fortuna A, Mercuri S (1983) Intradural spinal cysts. Acta Neurochir (Wien) 68: 289-314.

22. Agnoli AL, Schonmayr R, Laun A (1982) Intraspinal arachonid cysts. Acta Neurochir (Wien) 61: 291-302.

23. Catala M, Poirier J (1998) Arachnoid cysts: Histologic, embryologic and physiophatologic review. Rev Neurol (Paris) 154: 489-501.

24. Silbergleit R, Brunberg JA, Patel SC, Mehta BA, Aravapalli SR (1998) Imaging of spinal intradural arachnoid cysts: MRI, Myelography and CT. Neuroradiology 40: 664-668.

25. Arslan A, Karaslan E, Sirvanci M (2004) Cyst and cyst-like lesions of the spine and spinal cord: MR and MR myelography. Radiologist 11: 41-53.

26. Senol MG, Tekeli H, Kendirli MT, Kaya S, Turhan V, et al. (2012) Intramedullary hydatid cyst of the cervical spine. Indian J Med Microbiol 30:480-481. 